Academy of Management 2009 Best Paper Proceedings

\title{
AN OPTION TO PARTNER: A DYADIC ANALYSIS OF CVC RELATIONSHIPS
}

\author{
ANU WADHWA \\ College of Management of Technology, Ecole Polytechnique Fédérale de Lausanne \\ Lausanne, Switzerland \\ COREY PHELPS \\ University of Washington, Seattle
}

\section{INTRODUCTION}

A fundamental means by which firms explore and develop new resources and capabilities is through external initiatives such as corporate venture capital (CVC) investing, strategic alliances, and acquisitions (Keil, 2002). While acquisitions and strategic alliances have received substantial scholarly attention, research on CVC investing has only recently experienced renewed interest (Dushnitsky, 2006). CVC investments are direct minority equity investments made by established companies in privately-held entrepreneurial ventures (Dushnitsky, 2006). CVC relationships are exploratory initiatives because they establish boundary-spanning relationships with new ventures, which often pursue novel technologies and are an important source of knowledge for corporate investors (Dushnitsky \& Lenox, 2005). Although firms may seek direct financial returns from their CVC investments, strategic motives typically dominate financial incentives (Dushnitsky, 2006).

Due to their uncertain and exploratory nature and the limited access they provide, CVC relationships may be insufficient to realize strategic benefits. While some research shows CVC investing can increase investor performance (e.g., Dushnitsky \& Lenox, 2005, 2006), other research shows CVC investments can have diminishing and negative returns to investor innovation performance (Wadhwa \& Kotha, 2006). Moreover, CVC investing units often experience difficulty in facilitating the transfer of knowledge from their entrepreneurial ventures to their parent firms' business units that can benefit from this knowledge (Henderson \& Leleux, 2002). To realize the learning potential from CVC relationships and generate greater value from them, corporate investors may have to increase their involvement in their portfolio firms. One way to achieve this is through strategic alliances. Alliances differ from CVC relationships in that alliance partners mutually commit resources, beyond financial capital, to achieve a particular objective, while CVC investments entail a clear distinction between investors and users of funds and do not necessarily involve the mutual commitment of other firm resources (Dushnitsky \& Lavie, 2007). While alliances offer the potential of enhanced interfirm learning (Hamel, 1991), they involve a greater degree of commitment than CVC relationships. The risk of commitment is exacerbated by the substantial uncertainty that surrounds entrepreneurial ventures. Given this tension, this paper examines the conditions under which a CVC investment between a corporate investor and a venture leads to the formation of a strategic alliance between the two firms.

Research characterizes CVC investing as a flexible means of obtaining privileged access to information about future opportunities (Li \& Mahoney, 2006). Research shows firms use CVC investing to identify potential alliance partners and acquisition targets (Dushnitsky, 2006), and has examined the complementarities and trade-offs between CVC and alliances (Dushnitsky \& Lavie, 2007), the choice between CVC and acquisition (Tong \& Li, 2007) and the effect of prior CVC relationships on acquisition performance (Benson \& Ziedonis, 2009). Despite these studies, research has not investigated whether or when a CVC investment results in alliance formation.

The purpose of this study is to identify and empirically test factors that influence whether 
a venture and its corporate investor subsequently form a strategic alliance. Drawing on research that characterizes CVC investments as real options (e.g., Hurry, Miller \& Bowman, 1992), we argue an initial CVC investment creates a compound growth option. The formation of an alliance with a portfolio firm is akin to exercising the second stage of this option. We explore how different types of uncertainty and a corporate investor's resources influence the likelihood of alliance formation. We test our predictions on a sample of 256 investor-venture dyads.

\section{THEORY AND HYPOTHESES}

Real options confer the right, but not the obligation, to participate in a future strategic opportunity requiring more investment (Dixit \& Pindyck, 1994). Real options allow irreversible investments in uncertain opportunities to be deferred, thus reducing commitment and preserving flexibility (Folta, 1998). CVC investments serve as real options for investing firms (Allen \& Hevert, 2007), constituting relatively small, irreversible resource commitments to novel and uncertain initiatives. They allow firms to minimize commitment and downside risk, while retaining their ability to gain via subsequent investment from the upside potential of good ideas. Ventures have high dissolution rates and often work with new technologies in unproven markets, creating uncertainty about viability of the technology and venture. If the venture fails, its assets cannot be easily redeployed, making the investment largely irreversible (Li \& Mahoney, 2006).

A firm that makes a CVC investment in a new venture purchases a real call option (Hurry et al., 1992) and acquires the right, but not the obligation, to participate in three kinds of future decisions about the venture. First, in the presence of potentially unfavorable outcomes, the investor can minimize its losses by abandoning the option by selling or writing off its equity stake (Li \& Mahoney, 2006). Second, the investor can defer action to allow uncertainty to resolve over time. Third, CVC investments provide investors privileged access to valuable subsequent investment opportunities, or growth options (Li \& Mahoney, 2006). Growth options are flexible platforms that investors can leverage to develop new resources and respond to future opportunities (Kogut \& Kulatilaka, 2001). A subsequent investment in the venture represents the exercise of the option and may create an additional option. In addition to providing explicit and exercisable option rights, CVC investments are accompanied by implicit preferential claims in that investors have privileged access to information about the ventures (Dushnitsky, 2006). This information reduces investor uncertainty about venture quality and provides it an advantaged position relative to non-investors (Folta \& Miller, 2002).

We characterize CVC investments as two-stage compound options (Kogut, 1991). The first stage occurs when a firm purchases equity in a startup. The second stage corresponds to the exercise of the option by forming an alliance with the venture. Greater commitment of resources by a corporate investor via an alliance with a venture provides several benefits to the investor. Alliances provide corporate investors with access to venture knowledge and opportunities for interfirm learning (Hamel, 1991), beyond what passive equity investments alone provide. CVC investments that precede alliances limit downside risk for corporate investors by providing them with valuable information about their ventures' markets and technologies, allowing investors and ventures to make more informed and better decisions about alliance formation.

We argue the exercise of the second stage growth option is influenced by two types of external uncertainty - venture uncertainty and competitive uncertainty. We also argue corporate investors can use their technological resources to strengthen their portfolio firms' performance. This suggests that technologically rich investors may be able to endogenously reduce uncertainty in their portfolio firms and moderate the influence of external uncertainty on alliance formation. 


\section{Uncertainty}

Real options research emphasizes three types of uncertainty. Exogenous uncertainty is largely unaffected by firm actions and typically resolves over time (Folta, 1998), encouraging firms to delay investment (Dixit \& Pindyck, 1994). Endogenous uncertainty can be resolved by an investor's actions and motivates investors to invest sequentially (Folta, 1998). External uncertainty arises from sources external to the investor, but unlike exogenous uncertainty, it can be influenced by an investor's actions, allowing it to "act as an agent of endogenous change" by attempting to "shape the contingencies in its favor" (McGrath, 1997). We argue two types of external uncertainty, venture and competitive uncertainty, influence whether the CVC investor will exercise its second stage option in the form of an alliance.

Venture Uncertainty. In investment involving new ventures, uncertainty is often related to the market or technological arena the venture is pursuing. Accordingly, we focus on two types of uncertainty associated with new ventures - uncertainty related to their development (Venture Lifecycle Uncertainty) and uncertainty related to their technologies (Venture Technical Uncertainty). Corporate investors are likely to consider these types of venture uncertainty when deciding on whether and how to exercise growth options embedded in their CVC investments.

New ventures suffer from a "liability of newness" (Stinchcombe, 1965). In early stages of development, a venture's processes and systems are poorly developed and inefficient and it is less likely to attract stakeholders critical to its success. New ventures exhibit significant volatility in terms of their survival and future economic returns (Li \& Mahoney, 2006). This uncertainty declines as the venture matures, becomes more stable and legitimate (Aldrich \& Fiol, 1994). On the technological front, new ventures are typically engaged in developing novel technologies that are often associated with new technological trajectories in which technical standards have not congealed, performance metrics are contested, underlying cause-effect relationships are poorly understood, and technical advances are rapid, increasing the risk of obsolescence (Garud \& Rappa, 1994). This increases technical uncertainty, which reduces an investor's ability to value the technology and increases its risk of adversely selecting a mediocre technology. This uncertainty diminishes over time as the technology is improved and more information becomes available about its commercial viability. Thus, as a venture's lifecycle and technical uncertainty decline, a corporate investor is more likely to exercise its growth option by forming an alliance.

H1: Given a CVC investment by corporate investor i in venture j, Venture Lifecycle Uncertainty decreases the likelihood they will form a strategic alliance.

H2: Given a CVC investment by corporate investor i in venture $j$, Venture Technical Uncertainty decreases the likelihood they will form a strategic alliance.

Competitive Uncertainty. Unlike financial options, which tend to be exclusive, real options can be shared among several option holders (Kester, 1984), who may act preemptively to exercise their option and appropriate some or all of its value (Trigeorgis, 1996). When compound options are shared among firms, each firm may have different reasons for exercising the option, and may assign different values to the underlying assets. The actions of individual option holders can increase the price of exercising the second stage option or greatly reduce its value (Folta \& Miller, 2002). As more firms share an option, the uncertainty associated with capturing value from it increases. In such a competitive environment, if an investor fails to exercise the option it may be locked out in the future (McGrath \& Nerkar, 2004).

In the case of a compound option initiated by a CVC investment, a venture can receive funding from multiple investors, including traditional VCs and other corporation investors. Corporate investors typically co-invest with other VCs (Dushnitsky, 2006). After making a CVC 
investment, corporate investors who wish to exercise the growth options in their portfolio firms through alliances can face two forms of competitive uncertainty. First, other investors may prefer the venture to exit via an IPO or an acquisition, and may not want the venture to form an alliance or may have other partners in mind for the venture. Second, a corporate investor may face competition from other CVC investors who want to exercise their growth options through an alliance with the venture. Moreover, since ventures are constrained in their ability to form and maintain multiple alliances, they may choose to form deeper relationships with fewer corporate investors. In both situations, waiting to exercise growth options through strategic alliances carries a threat of preemptive action by other investors and the corresponding loss of option value for the focal investor. As the number of other VCs that have invested in a venture increase, the threat of pre-emption increases, which increases competitive uncertainty. Thus, competitive uncertainty will positively affect alliance formation.

H3: Given a CVC investment by corporate investor i in venture j, Competitive

Uncertainty increases the likelihood they will form a strategic alliance.

\section{Investor Technological Resources}

In addition to the influence of external uncertainty, corporate investors' choices are also influenced by their own resources (Li \& Mahoney, 2006). An investor's technological resources influence its perception of the uncertainty associated with a venture as well as its ability to diminish this uncertainty. Since investing firms possess heterogeneous resources and capabilities, they are likely to differ in how they perceive the uncertainty underlying a new venture. Firms with greater technical resources are better able to evaluate the technology of a venture and recognize how they can help the venture successfully commercialize its technology (Keil, 2002).

Ventures also benefit from forming relationships with more technologically capable partners, which lower the uncertainty associated with the ventures. First, new ventures often do not possess the necessary complementary technical expertise to make their technologies a success. Corporate investors that possess these resources are in a better position to assist new ventures in successfully commercializing their technologies and entering new markets (Maula, 2001), thereby reducing the uncertainty associated with these technologies. Second, a corporate investor's technological resources will also reduce uncertainty associated with the developmental stage of a venture. Relationships with resource rich partners send positive signals of venture quality to other stakeholders (Stuart, Hoang \& Hybels, 1999). When a corporate investor with deep technological resources signals support for a new venture, the venture gains legitimacy in the market, which can stimulate demand for its offerings. The more technologically competent the partners, the greater are the expected benefits to ventures. Because a corporate investor's resources can reduce the lifecycle and technical uncertainty of a new venture, it can increase the venture's economic value and decrease the investor's incentive to wait for uncertainty resolution.

H4: Investor Technological Resources will weaken the negative relationship between Venture Lifecycle Uncertainty and the likelihood of alliance formation.

H5: Investor Technological Resources will weaken the negative relationship between Venture Technical Uncertainty and the likelihood of alliance formation.

The technological resources of a corporate investor will moderate the effect of competitive uncertainty. Since technologically rich corporate investors are better able to help ventures succeed and are more attractive partners for them, the risk of pre-emption by other investors is mitigated, decreasing the influence of competitive uncertainty.

H6: Investor Technological Resources will weaken the positive relationship between Competitive Uncertainty and the likelihood of alliance formation. 


\section{METHODS AND RESULTS}

The setting for this study is the global telecommunications equipment industry. The sample consists of 256 investor-venture dyads involving 28 publicly-traded telecom equipment manufacturers that invested in 227 new ventures for the first time between 1995 and 1999. Table 1 lists variables. Given the binary nature of the dependant variable, we use binary logit regression to estimate the data. Table 2 reports selected models from the regression analysis.

Insert Tables 1 and 2 about here

Hypothesis 1 predicted a negative effect of Venture Lifecycle Uncertainty on the probability of alliance formation. In Models 1-5, Venture Lifecycle Uncertainty is negative and significant, providing support for H1. Hypothesis 2 proposed Venture Technical Uncertainty is negatively associated with alliance formation. Results from Model 1-2 provide support for this hypothesis. The statistical insignificance of the simple effect of this variable in Models 3 and 4 is likely due to multicollinearity with the interaction terms which include this same variable. When we remove the non-significant interaction term including Venture Technical Uncertainty, the effect of Venture Technical Uncertainty becomes significant (Model 5). Thus, we find support for Hypothesis 2. Hypothesis 3 posited a positive effect of Competitive Uncertainty on the likelihood of alliance formation. In Models 1-5, Competitive Uncertainty is positive and significant, providing support for H3. Of the three hypothesized interaction effects (H4-H6), we find support for H4 and H6. The interaction of Venture Lifecycle Uncertainty and Investor Technological Resources is significant and positive, supporting H4. The interaction of Investor Technological Resources and Competitive Uncertainty is significantly negative, supporting H6.

\section{DISCUSSION \& CONCLUSION}

The purpose of this study was to investigate the conditions under which a CVC investment between a corporate investor and venture leads to the formation of a strategic alliance between the two firms. We make contributions to several research literatures. First, we contribute to the corporate entrepreneurship literature. While research has examined a variety of external corporate venturing initiatives, most of this research examines these initiatives in isolation. Little research has examined when and if these activities complement or substitute for one another. The results of this study suggest that, under certain conditions, CVC investing and alliances are complementary venturing activities. Our results also shed light on how corporate investors attempt to create value from and through their investments. We find an investor's technological resources play an important role in reducing venture uncertainty and in facilitating its involvement in its portfolio firms to increase the benefits from such collaboration. Second, our results have implications for the real options literature. While research has examined how uncertainty influences the creation and exercise of options, it has typically treated uncertainty as either exogenous or endogenous. We examine how different aspects of "external” uncertainty, which combines aspects of both exogenous and endogenous uncertainty, influence the creation and exercise of growth options. We also integrate firm heterogeneity into real options reasoning and highlight the role of investor resources in overcoming some of the uncertainty associated with these investments. Finally, we contribute to research on alliance formation. Although this research shows firms tend to form new alliances with firms they have allied with in the past as a way to manage partner uncertainty (e.g., Gulati, 1995), it has largely ignored the origins of the 
initial alliances from which future alliances grow (Hallen, 2008). Recent studies suggest initial alliances often evolve from prior interpersonal relationships between members of the firms (Rosenkopf et al., 2001; Hallen, 2008). We add to this research by showing that CVC investments can also provide the initial tie between firms from which future alliances can grow.

\section{REFERENCES AVAILABLE FROM THE AUTHORS}

Table 1: Measures

\begin{tabular}{|l|l|}
\hline VARIABLE & DEFINITION / OPERATIONALIZATION \\
\hline Dependent Variable \\
\hline $\begin{array}{l}\text { Alliance } \\
\text { Formed }\end{array}$ & $\begin{array}{l}\text { Dichotomous variable assigned a value of “1” if the existing CVC dyad } \\
\text { involving corporate investor } i \text { and venture } j \text { subsequently formed an alliance. }\end{array}$ \\
\hline Explanatory Variables \\
\hline $\begin{array}{l}\text { Venture } \\
\text { Lifecycle } \\
\text { Uncertainty }\end{array}$ & $\begin{array}{l}\text { This variable was ordinally coded based on its stage of development: 4 (seed/ } \\
\text { startup stage), 3 (expansion stage), 2 (mature), and 1 (buyout). Higher values } \\
\text { reflect greater venture uncertainty since they reflect earlier development stages. }\end{array}$ \\
\hline $\begin{array}{l}\text { Venture } \\
\text { Technical } \\
\text { Uncertainty }\end{array}$ & $\begin{array}{l}\text { The number of patents granted to the new venture. This variable was reverse } \\
\text { coded so that more venture patents were associated with lower values of } \\
\text { Venture Technical Uncertainty. }\end{array}$ \\
\hline $\begin{array}{l}\text { Competitive } \\
\text { Uncertainty }\end{array}$ & $\begin{array}{l}\text { The number of other investors that also invested in the venture, including } \\
\text { traditional and corporate venture capitalists. The greater the number of other } \\
\text { investors, the greater is Competitive Uncertainty. }\end{array}$ \\
\hline $\begin{array}{l}\text { Investor Tech. } \\
\text { Resources }\end{array}$ & The log of annual R\&D expenditures (in \$US million) of the corporate investor. \\
\hline Control Variables \\
\hline Investor Size & Natural log of annual sales (in \$US million) for corporate investor \\
\hline Investor Age & Number of years from the date of founding of corporate investor \\
\hline $\begin{array}{l}\text { Prior Investor } \\
\text { Alliances }\end{array}$ & $\begin{array}{l}\text { Number of alliances, not including those involving portfolio firms, formed by } \\
\text { corporate investor } i \text { during the four years prior to the CVC investment }\end{array}$ \\
\hline
\end{tabular}

Table 2: Logistic Regression Analysis

\begin{tabular}{|c|c|c|c|c|c|}
\hline Variables & Model 1 & Model 2 & Model 3 & Model 4 & Model 5 \\
\hline Investor Tech. Resources & $0.646 *$ & -0.336 & -0.097 & -0.141 & -0.383 \\
\hline Venture Life Cycle Uncertainty & $-0.409 *$ & $-3.106 *$ & $-3.290 *$ & $-3.941 * *$ & $-3.743 * *$ \\
\hline Venture Technical Uncertainty & $-0.029+$ & $-0.025+$ & 0.009 & 0.008 & $-0.027 *$ \\
\hline $\begin{array}{l}\text { Competitive Uncertainty } \\
\text { Venture Life Cycle Uncertainty X }\end{array}$ & $0.003^{*}$ & $0.003^{*}$ & $0.003^{*}$ & $0.013 *$ & $0.013 *$ \\
\hline $\begin{array}{l}\text { Investor Tech. Resources } \\
\text { Venture Technical Uncertainty X }\end{array}$ & & $0.368 *$ & $0.393^{*}$ & $0.479 *$ & $0.452 *$ \\
\hline $\begin{array}{l}\text { Investor Tech. Resources } \\
\text { Competitive Uncertainty X }\end{array}$ & & & -0.005 & -0.005 & \\
\hline Investor Tech. Resources & & & & $-0.001+$ & $-0.001+$ \\
\hline Log Likelihood & -125.83 & -123.689 & -123.609 & -122.66 & -122.744 \\
\hline Wald Chi 2 & $27.128 * * *$ & $31.41 * * *$ & $31.57 * * *$ & $33.468 * * *$ & $33.301 * * *$ \\
\hline
\end{tabular}

